\title{
Critical reflections on polygamy in the African Christian context ${ }^{1}$
}

\section{Elijah M. Baloyi²}

\section{Abstract}

Polygamy is a phenomenon often associated with African people. In almost all African societies, polygamy is an acceptable and valid form of marriage - in fact, monogamy has been associated with people of lower social status. Proponents of polygamy have claimed that the more wives a man has, the more children he is likely to have, and the more children, the greater the chances that the family will enjoy immortality. This is indicative of the high regard in which the tradition is held by some African people (men in particular). The theological thinking of various Christian denominations is divided on the subject of polygamy. The intention of this article is to investigate the way in which African people have conceptualised polygamy, and how the Christian church has dealt with it. In particular, I will explore and present and argument on whether polygamy can still be regarded as acceptable in contemporary Christian communities.

\section{Introduction}

Kyomo and Selvan (2004:35) confirm the contemporary relevance of polygamy as a topic of discussion, stating: "Polygamy has been a widely discussed topic in African theology since the 1960s and it is a burning issue even today.” While various religious communities and Christian churches have been debating the permissibility of granting church membership to male polygamists, other groups have argued about whether or not polygamy is a cultural mandate in South Africa. For some it is an embodiment of Old Testament practices, and therefore has no place in modern society, while others regard it as a pagan practice. I do not, in this article, intend to participate in such arguments; instead, I wish to reveal the oppressive nature of the practice in its treatment of women. The election of President Zuma, in South Africa, has raised the profile of polygamy (Wunderink 2009:17), but Isabel Phiri (a theology professor in KwaZulu-Natal) expresses concern at the fact that, traditionally, "polygamy, which was a practice of rich men with the land and money to support a large family, is now practised by middle-class and poor men” (Wunderink 2009:18). According to Kahiga (2007:125), supporters of polygamy have customarily argued, in various cultural contexts, that to marry one wife is like being one-eyed, while having two wives can be compared to having two eyes, and therefore being

1 This article is a revised version of the paper delivered at the law conference held at the University of Limpopo, 29 August to 2 September 2011.

2 ME Baloyi teaches Practical Theology in the Department of Philosophy, Practical and Systematic Theology at the University of South Africa. He can be contacted at baloye@unisa.ac.za. 
capable of seeing far more. The questions of whether polygamy is culturally acceptable or not, or whether it is good or bad, are not the focus of this article. To my mind, the important question is whether or not polygamy encourages the abusive treatment of women. In writing this article, my aim has been both to reveal the abusive nature of the practice, and, as Majeed (2004:74) argues, to show how the practice is a challenge to historians, sociologists, theologians, anthropologists and other scholars. To reiterate: the main concern of the present article is to focus on polygamy as one of the manifestations of the oppression of women in different African cultural contexts (Kahiga 2007:120). In this, I support Mbeya (1994:25), who states that any aspect of African culture which keeps women in bondage or reinforces their inferiority must be challenged.

\section{Purpose and research problem}

While some churches are reluctant to allow women or the wives of polygamists to occupy prominent positions within the church, others are reluctant to permit a polygamist to occupy a church leadership role. Yet others, such as some of the African Independent Churches, accommodate polygamists and allow them full and active participation in the life of the church. Decisions such as this determine how the church (a particular denomination) will be accommodated or receive support in a particular area, particularly in rural areas where traditions are still held in high esteem. One of the research questions to which I sought answers was whether the denominations that reject polygamy would change their stance in order to gain more members in the persons of polygamists, or would remain true to their principles even though this would mean a dwindling membership. The fact that the Christian church is divided on this issue signals the existence of a problem necessitating research. It is therefore the intention of this article to explore the African traditional reasons for men marrying more than one wife, and to examine the Christian view of this practice. By Christian view I mean the view of both groups of the divided Christian fraternity, whose arguments I will critically assess. An important aspect of the research will entail an examination of the effects of the practice, and as part of the critical assessment, some advice from the Bible will be offered.

\section{The meaning of polygamy and its historical roots}

Polygamy is not the sole preserve of African people:

From its Greek origin, the word polygamy is understood in the broader sense to include any simultaneous multiple marriage unions for one person, such as female polyandry and male polygyny; however, the word polygamy is used throughout this work to describe the state of a man having more than one woman, including the religious, legal and customary aspects of these unions (Yamani, 2008:xi). 
According to Gaskiyane (2000:97), the concept is defined as a culturally determined, socially acceptable and legally recognised form of permanent marriage where a man has more than one wife at a time. In this case, the acceptability of the marriage is determined by the social customs of the people concerned. Kahiga (2007:120) observes that different meanings may be inferred contextually, but in essence polygamy refers to marriage where more than one wife is involved.

Shahzad (2009) states that polygamy is as old as human society, and cites David and Solomon as just two among many examples. Although it is difficult to say whether polygamy is increasing or decreasing, it remains a significant and widespread phenomenon (Okorie 1995:1).

Kahiga (2007:120) is of the opinion that while polygamy was formalised in Africa, it has taken the form of anonymous polygamy, with partners or concubines incognito in different locations. Kahiga argues that the cycle of divorce and remarriage in the West amounts to successive polygamy, because either partner is welcome to remarry after the divorce. For him it is generally felt that when white people came to Africa, they and the church combined in their endeavours to abolish polygamy. Hillman (1975:182) argues that although some of the Reformers viewed polygamy as not being contrary to the law, Calvin insisted that monogamy was prescribed by natural law. In the words of Maillu (1988:1): “The colonial church in particular, has been fighting against the tradition on the basis that it is incompatible with the Bible." Although this may have reflected the views of many, numerous divergent arguments have been put forward by African scholars and missionaries: while Bishop Josiah Kibira of the Evangelical Lutheran Church in Tanzania acknowledged the difficulties presented by polygamy and called for theological study, the Anglican church in West Africa allowed the wives of polygamists to be baptised although the same church in South Africa and elsewhere refused to admit them even to the catechumenate without the authorisation of the bishop. The Liberian Lutheran church elected to accept polygamists and their wives to baptism and Holy Communion, while in 1967 the regional conference in Nairobi asked the Roman Catholic bishops to reconsider the possibility of adopting new policy regarding polygamy (Hillman 1975:35).

Okonkwo (2003:15) states:

If we seek to identify the main distinguishing feature of African customary marriage as compared with European marriage, there will no doubt be general agreement that the most obvious of such features is the toleration and even approval, accorded to polygamy.

Although Okonkwo may be correct, it would be incorrect to generalise and assume every African to be a polygamist, particularly in the present day, in light of the current socio-economic situation and the criticism expressed by some Christian churches. Bishop Colenso (the English-born Methodist 
missionary who carried out his work during the 1800s in what is now KwaZulu-Natal) is one of those who raised eyebrows because of his tolerance of polygamy, famously recorded in his "Remarks on the proper treatment of cases of polygamy, as found already existing in converts from heathenism."

According to Masenya (2005:188), Sotho sayings such as Monna ke tshwene, oja ka matsogo a mabedi (literally meaning "a man is a baboon, he eats with both hands", in other words, a man may have more than one wife) not only reinforce the subjugation of women, but also make women vulnerable to the HIV/AIDS pandemic. Phiri (2007:75) draws attention to the abuse and violation suffered by women when missionaries from the Roman Catholic and the Dutch Reformed Church in Malawi insisted that polygamists divorce their wives to remain with one upon conversion and baptism; many deserted women were left with the crippling economic burden of caring for their children and household.

Ford (2007) reports that the decisive issues identified by the Circle of Concerned African Women Theologians, in dialogue with the West, include violence against women, in which polygamy and male control in the regulation of sex play a role. The Circle of Concerned African Women Theologians considered polygamy to be not only patriarchal, but a further form of violence against women. As Njoroge (1997) so rightly states, the unlearning of internalised sexist practices, attitudes and beliefs and patterns is one of the greatest challenges facing women.

In her paper entitled Christene en poligamie, Landman (2010) draws together a range of controversies relating to polygamy from Roman times through to the debates that took place at the World Council of Churches General Assembly of 1988 in Harare, Zimbabwe. For Landman, it is the principle of equality that matters. She acknowledges that polygamy is not condemned in the Bible, and argues that whatever the context of polygamy, the most important consideration is whether the participants in the relationship treat one another equally, and in that way follow the example set by Jesus.

Although the Recognition of Customary Marriages Act 120 of 1988 extends the state's recognition and regulation to both monogamous and polygamous customary marriages, the bill of rights by extension entrenches the rights of women in polygamous marriages not to be discriminated against (Vos 2010). Moreover, the bill of rights by extension also entrenches the rights of children born of a polygamous marriage to education, which could increase the economic burden on the polygamist. Therefore most South Africans, particularly ordinary people, prefer to avoid the problems associated with polygamy by having only one spouse.

Phiri (2006:6) suggests that polygamous and levirate marriages can be traced to the fact that the biblical stories were told, written and interpreted 
in a male-dominated society. A more recent example involves the South African president, Jacob Zuma, who in 2012 married his fourth wife. Karimi (2012) reported as follows on this event:

Zuma, 70, tied the knot with Bongi Ngema in a traditional ceremony Friday in the town of Inkandla. It is the sixth marriage overall for the polygamous president. While legal in South Africa, polygamy is losing popularity with the younger generation in the continent, while it is still practiced in some cultures.

According to Wunderink (2009), polygamy has long been a challenge for Christians in countries with predominantly Muslim populations and many parts of Africa. Therefore, although polygamy has been an accepted form of marriage in most African societies (Waruta and Kinoti 2000:105), engagement on this topic is still very important and relevant to the contemporary church and its people.

\section{Functions served by polygamy in the African context}

A number of cultures practise polygamy for the same reasons. While the present study focuses on African people and their practising of this custom, I do from time to time refer to cultures from outside Africa to illustrate that African people do not live in isolation, and to indicate the commonality between all peoples.

\section{A remedy for the problem of infertility}

Mbiti (1969:105) conveys the importance of childbearing in African marriages, stating: "Marriage and childbearing are the medicines against death. While death continues to demolish life, marriage and childbearing keep ahead of it all the time.” One is reminded here of the story of Abraham and Hagar, which suggests the permissibility of polygamy in instances of barrenness. Cairncross (1974:69) cites the argument as follows: "If a wife is a barren it is indeed her duty to give such a consent, and even to exhort the husband to take another companion as Sarah did of old.” This argument is also favoured by Maillu (1988:8), who suggests that polygamy is the kindest solution in the case of a wife who is infertile, because this is preferable to being expelled from the household, and having to look for another husband.

Kofon (1992:52) explains:

In Bafut (and other parts of Africa) people marry because they want to have children. This is the principal aim. There is no marrying simply for personal fulfilment or for mutual pleasure of the spouses. Begetting children is a duty to be fulfilled.

This view is echoed by Yamani (2008), who reports: “A wife's infertility is a valid reason for her husband to polygamously seek another.” Traditionally, 
marriage and child-bearing had a cause-and-effect order that was difficult to break (Burman 1991:36).

According to Turaki (1999:107), begetting children guaranteed eternal life. A traditional African man needs many children (especially sons) to ensure the survival of the lineage and to increase his power within the clan (Nhlapo 1992:143). Gaskiyane (2000:23) reports:

A few groups within nominal Christendom believe that the bearing of a very large number of physical children brings eternal blessing and that such families continue together forever in Heaven. From this belief some African people believe that polygamy is blessed by God.

These arguments all serve to support Mbiti's statement (1969:133) that "Marriage and procreation amongst the African communities are a unity; without procreation, such marriage is incomplete".

Kimathi (1994:12) and Gaskiyane (2000:10) report that some African people invoke polygamy to prevent a possible divorce, particularly in cases where childlessness or barrenness was anticipated. In this context Waruta and Kinothi (2000:105) state: "In traditional African society, it was almost inconceivable that a childless marriage could be sustained monogynously." This practice also became a solution for marriages where only female children were born, since the importance of male children was emphasized (Kyomo and Selvan 2004:36). Gaskiyane (2000:15) elucidates: "In traditional cultures the greatest desire and requirement is to have children, especially male children, to be heirs of property." In this context, Waruta and Kinoti (2000:36) further contend that "Not only is the birth of a child important amongst the African people, but the gender of the child is also important. Male children are valued, especially in many patrilineal African societies.”

\section{A solution in the event of menopause}

Among some African people it has long been accepted that women may no longer engage in sexual activities once they have entered menopause. Kimathi (1994:13) explains:

Menopause among many ethnic groups brought an end to the need for sexual activities. A woman with married daughters and sons was regarded as somebody who had finished her sexual role in marriage. She now was considered too old for sexual encounters. This was something that was regarded as a duty for the younger wives. It is not surprising, therefore, that an older woman would tell her husband that it was time he got himself a new wife as an indication that she was ready for exemption from her sexual obligations.

This explanation provides a clear indication that, according to some African people, sexual responsibility for women was limited in duration, but that men were allowed to continue to have sexual relations after women were 
expected to stop. This emphasises that sexual relations, for African women, were aimed mainly at procreation, which was why, once a woman reached menopause, there was no need for her to continue to engage in sexual intercourse. Peil and Oyeneve (1998:35) thus claim that a marriage is considered to have ended once the woman is past child-bearing age.

Kyomo and Selvan make the same point: "One reason for polygamy seems to be the old taboo of menopause. Many African people believe that a woman should not have sexual intercourse after menopause". It was believed that a woman who broke this taboo would be physically punished: her stomach would grow bigger and bigger, or else the seminal fluid accumulated in her stomach would flow out through the genital orifice, creating an unpleasant odour (Kyomo and Selvan 2004:35, 36).

\section{A solution during pregnancy and nursing}

Some African cultures forbid sexual relations between a husband and wife during pregnancy; in this regard, Labeodan (2007:46) reports:

Most of the women confirmed that once they have 'taken in' (become pregnant), they cease having sexual relationships with their husbands, resuming only after three years have passed and the baby is weaned.

In some Asian and Latin American cultures, too, women abstain from sex during pregnancy (Maldonado, [s.a.]:30).

Kofon (1992:52) makes the observation that some African people believe that when a wife is nursing a child, sexual intercourse is forbidden; because the husband may be unwilling to wait for three years before resuming sexual relations, he might have more than one wife. In some instances the woman herself may suggest that he take another wife, as this may reduce the chance of his being unfaithful during such a long period of abstinence. It was therefore believed in most polygamous cultures that once a man had more than one wife, immorality and divorce would be unlikely to occur. Kofon (1992:56) summarises this reasoning as follows: "Polygamy is supported in Africa for the reason of sexual gratification when one wife is ill or is delivered."

\section{A remedy against social exclusion}

In many African cultures it is the norm for an adult to be married and to have children. Kimathi (1994:40) goes so far as to term marriage the backbone of African society. Single status in African cultures has a number of negative associations - one being witchcraft (Phaswana 2005:1). The Sotho idiom Lebitla la mosadi ke bohadi (meaning that a woman's grave lies in her marriage or her in-laws) expresses the requirement that women should remain in their marriage, even if that marriage is life-threatening (Kriel 1991:27). Single women have always been suspected of many evils, such as lack of feeling and a desire to break up other people's marriages. 
Phiri (2002:25) notes the belief among Africans that being single is a curse; Kathide (2007:40) articulates the similar view that since it is a disgrace to be unmarried, polygamy offers every woman a chance to be married and thus fit in with the norms of society.

This puts enormous pressure on unmarried women, and, in fact, remaining a single person in an African context is an extremely difficult choice to make. The belief that every woman must have a husband and every man a wife has created a situation where a woman would prefer to be one of several wives rather than be without a husband, as the latter situation would make her a social outcast (Gaskiyane 2000:17). In the words of Baloyi (2010:3):

There are people who get married not necessarily because they want to, but because they feel the pressure of being single. Such marriages seldom last since they will lack commitment which is needed for every marriage to survive.

Above these arguments, Reynolds (2008:123) points out that there are many reminders to unmarried women that they are not living a 'normal' lifestyle.

\section{A source of labour}

In most African cultures men (males) are generally assumed to be the breadwinners. Stock and crop farming were the common means of survival, and both require strength and labour. This led Townshend (2008:37) to suggest that polygamy was originally a means by which men acquired status and labour, as the more wives a man had, the more children he could have and the greater would be his labour force. Taking care of livestock and ploughing of fields would be easier if there were more people than if this were the responsibility of just one person (the man himself). Thus labour became a commodity in male-dominated societies where polygamy was customary. Fenske (2012) points out that the demand for wives is highest in those parts of the Ivory Coast where female productivity in agriculture is highest. Similarly, Kathide (2007:39) observes that in Africa where peasant farming was the means of livelihood, the many children born of a polygamous marriage would become economic assets as a source of labour in the fields. Thus the economic motive becomes a very important factor in the context of polygamy (Blum 1989:98). In my view this is a form of child enslavement, with concomitant negative effects on children's education.

\section{Fulfilment of the desire for a male heir}

Many Africans believe that it is best to train their own blood sons to take over whatever they own. Although Phiri (2002:37) recounts that among the Chewa people in Kenya songs are sung to the effect that she who has given birth to a baby girl is rich, while she who has given birth to a baby boy is poor, for many African families a male heir has always been the objective - 
hence Kimathi's (1994:12) statement that a marriage into which only girls were born is to be pitied. The mother of girls is often blamed by her husband and his parents for not producing sons. In the past, sonless marriage always stood on shaky grounds. It was often a cause for polygamy.

Many other researchers have contrasted the celebration attendant on the birth of boys and the less enthusiastic reception given to girls in African families. One is reminded of the traditional Tsonga saying: "Vanhwana i tihuku to khomela vayeni," the literal meaning of which is "girls are chickens for visitors" - in other words, girls will not stay in their home forever because they will get married, but boys will stay, ensuring that the elderly parents will have an heir who will take care of them.

\section{A wife's ill health, absence and the phenomenon of working mothers}

In a traditional African context, his wife's ill health is not seen as a reason for a husband to abstain from sex. If his wife was ill for a long period, the husband's family would encourage him to think of a second marriage, reasoning that this would give the first wife time to recover. It was further reasoned that the second wife would help to nurse the sick woman and ensure that the children were taken care of (Maillu 1988:18). It has also been claimed that if women are regularly absent from home because they work far away, they would ask their husbands to marry a second wife (Modupe [s.a.]:14). However, I believe that it is possible to challenge such reasoning. The family would not apply the same principle if the husband were the one ill. Moreover, it is unconscionable that instead of supporting his wife during her time of need a man would devote his time to entertaining a new wife. With regard to the issue of women working far from home as a reason for polygamy, I can only respond by saying that in the past husbands and fathers used to work very far from home, but visited their families regularly, as a result of which there was no need for additional wives. Women working far from home could do likewise, and again, there would be no need for polygamy. In any event, Christian marital vows include the promise of support in health and in sickness, which cannot simply be ignored in difficult times.

\section{Sexual incompatibility}

Mbiti (1969:143) and Kathide (2007:40) agree that polygamy, when viewed as a preventive measure against unfaithfulness, allowed a man who worked far from home to take one wife with him to his place of work (possibly a distant city or town) while another wife or other wives continued taking care of children and the household in the rural area. In such a situation the husband would be unlikely to have concubines or frequent female prostitutes in town. 
Maillu (1988:9) suggests that if a wife is less interested in sex than her husband, this is a justifiable reason for him to take an additional wife. Okorie (1995:3) expresses a similar sentiment, suggesting that polygamy results in less temptation for a man to commit adultery.

This, however, is a clearly patriarchal view of sex which promotes male supremacy and perpetuates the gender imbalance in society.

\section{A way of taking care of widows}

Okorie (1995:3) cites a widely African belief that levirate marriage constitutes a means of taking care of widows. Levirate marriage is seen as a way of protecting both the widow and her children, who will be taken care of by the younger brother of the deceased. Moreover, it is a way of ensuring stability and that the widow will not become part of another family, taking the wealth of the deceased with her. However, not all widows are receptive to this practice: Nkhwashu (2012) cites the example of a young widow who fled from the prospect of being forced to marry her late husband's younger brother, taking with her the compensation paid out to her by her late husband's former employer.

\section{The African Christian view of polygamy and its effects}

Maillu (1988:1) argues that besides being an entrenched custom in Africa, polygamy features in the oldest historical records. Gold (2007:1) cites the example of an African pastor who taught his church under the title: "Polygamy as a pre-requisite for church membership." According to Gold (2007:1) the Langham Partnership makes the observation that interpreting and applying the Bible in the light of African culture and realities furnishes powerful and relevant insights into the biblical text that transcend Africa in their significance. Muslims practise polygamy. Saint Augustine and Saint Thomas Aquinas taught that simultaneous polygamy is not in itself evil, since it was permitted by God in the Old Testament (Hillmann 1975:179); they viewed it as being contrary neither to the law of nature nor to the nature of the Bible.

In the African context, Christian churches were and still are divided into three categories: the missionary-initiated churches (the so-called mainline churches), the African Independent Churches (AICs), and the Pentecostal churches. For the Christian missionaries who first came to Africa, monogamous marriage was the norm. Furthermore, throughout the centuries, the teaching of the Christian church about marriage has emphasised monogamy. In the words of Waruta and Kinothi (2000:108):

Western missionary Christianity - with its insistence on monogamy as the only acceptable form of marriage, its emphasis that marriage is primarily a matter of a man or a woman 'leaving his or her mother and father and the two becoming one flesh', its largely puritanical if not hypocritical attitude 
toward human sexuality, and its preference for a more individualistic lifestyle and nuclear families, has created much confusion and anxiety in contemporary African society.

Earlier Western missionaries felt the need to confront polygamy at the point of conversion. In short, a man who wanted to be accepted as a church member was required to bring one wife into the church (where a formal church marriage ceremony would take place) after abandoning all the other wives, in order to remain in monogamous marriage. However, as Mugambi (1989:96) points out, this "common rule" did not bring an easy solution to this problem. In this regard Wunderink (2009:18) quotes Isabel Phiri, who argues that this is an example of where missionaries with good intentions did not have a proper solution to the issue of polygamy, and in fact promoted divorce without responsibility being taken for the children. Bishop John Colenso of Natal recognised this when acknowledging that the practice of separating husbands and wives on their conversion to Christianity is in opposition to God's teaching (Hillmann 1975:32). As Jenkins (2010:45) remarks: "This policy initially limited the impact of the so-called mission churches, while pushing believers toward new independent congregations, the African Initiated Churches or AICs.”

Jenkins's (2010) observation gives us some insight into the AICs as churches that accommodated polygamists as full members. In the view of Jerkins James $\mathrm{O}$ Kombo, lecturer at Daystar University in Kenya, African-initiated churches are more welcoming, and one would probably find a number of (polygamous) families among the members of their congregations. The same sentiment is expressed by Hillman (1975:33), who states: "On the whole it is the Independent African Churches, composed initially of dissident Christians from Western-based churches, that have taken the more lenient positions.” De Bruyn (1988) reports that Densen Mafinyani took a stance on behalf of the Zimbabwean Council of Churches (ZCC) against the World Council of Churches (WCC), recommending that the latter should accept as members those churches which tolerate polygamy, because in the African context polygamy is neither wrong nor evil. Not all AICs require a polygamist to dismiss all but one of his wives in order to join the church, because the African epistemology differs from the Western epistemology and recognises both monogamous and polygamous unions as indissoluble; it also articulates that divorce is not an African, but a Western concept (Kahiga 2007:131). Some AICs opted not to resist polygamy, believing that "official polygamy" 3 was not a great problem, but that "unofficial polygamy"4 was. It was as a result of this difference in

3 Official polygamy refers to a situation in which all wives are married through the customary payment of lobolo.

4 Unofficial polygamy (nke mdogo in Swahili) refers to a situation in which marriage to a second or third wife is not sealed by the payment of lobolo. 
outlook between the missionary churches and the AICs that the latter drew more converts (who felt ill-treated by the former).

It is claimed that the husband and the first wife often reach agreement concerning the husband's marrying a second wife. Kahiga (2007:127) disagrees:

Women who accept second marriage to their husbands have no choice but to toe the cultural line. It is not that a woman is so generous to suggest to a man to take a second wife, no, it is her pre-emptive action to forestall the man from bringing a second wife that will contribute to disharmony and perpetual wars in the extended family

In other words, the first wife is faced with a choice either to choose an acceptable second wife or to leave this entirely up to her husband. This is why the wife will usually choose a young woman who is her friend or a relative and recommend her to the husband, because the first wife has a much better chance of commanding respect from a woman she knows than from stranger.

According to Gaskiyane (2000:10), there is plenty of evidence to show that "no woman really wants to share the affection and love of her husband with another woman". The testimony of those who have lived in polygamous homes around the world supports the fact that jealousy and bias always prevail. (In the Old Testament, Jacob favoured Rachel over Leah and Elkanah favoured Hannah over Peninnah (1 Samuel 1:5) (Gaskiyane 2000:9). Kahiga (2007:127-128) states:

If marriage entails that a man gives himself to a woman and a woman gives herself to a man, what then is left to give to another (third person) woman? The man will not be available unless as a fake man, an illusion a mere physical and not mental, spiritual complete presence to the other. In this case the woman will be taken as an object but not as an equal subject, a means but not an end in herself. Therefore polygamy or anonymous polygamy is a lie and an intellectual dishonesty.

Although some church leaders initially rejected polygamous marriages in their churches, Wunderink (2009:1) reports that many African church leaders regret zero-tolerance policies applied to polygamous families of converts, saying that treating those marriages as invalid gives rise to a number of problems.

\section{Critical evaluation}

Among the things that a critical evaluation of polygamy helps us to see is that not only does it encourage the treatment of women as inferior beings, but it also foments rivalry between wives and forces many women to share already scarce resources with co-wives and their children. It also has an impact on women's health, and has a detrimental effect on the many 
children that the polygamist will have (Struensee 2004). Okorie (1995:6) mentions the jealousy and intense envy that polygamy gives rise to among the wives. With reference to the often-cited polygamy of the President Zuma, one of the most important issues is that of leading by example. If we examine his polygamous marriage in the light of issues such as HIV/Aids and accountability, the president has failed to set a good example, particularly for the younger generation, who require guidance and education in marital issues. It is important to ensure that from their leaders, including political leaders, the younger generation, and indeed society at large, should learn responsibility and accountability in matters related to marriage.

As far as the issue of infertility is concerned, it seems that, in African culture, it is the woman who is usually suspected of being infertile, even if medical tests have not been conducted. Kimathi (1994:23) reports on a case study involving a woman who was unable to conceive. Following a medical examination that confirmed that there was nothing wrong with her, the doctor suggested that her husband should also come for a medical examination; the husband refused to do this. His refusal, of course, suggests that he had every intention of choosing to believe that there was nothing wrong with him and that he was entitled to continue to blame his wife for their childless state. This is yet another example of how African tradition tends to be judgmental of women, even in the face of medical evidence to the contrary. As Gaskiyane (2000:10) rightly points out, in some cases at least, polygamy follows on from a man's unwillingness to acknowledge that problems relating to infertility may lie with him.

In some cases, where men have been tested and found to be sterile, they have demanded that the doctor never disclose this information (Gaskiyane 2000:11). This is precisely why Baloyi (2010:12) recommends that, before a man marries a second wife for reasons of infertility, both he and the first wife undergo medical tests to ascertain which of the two is infertile. This will not only reduce the tendency to automatically blame the woman, but will also enable the medical profession to help the couple before a third party is involved. It is vital that Christian communities be educated to understand that marriage is not intended for child-bearing only, but also for the achievement of goals such as friendship, intimacy, complementarity and partnership (Baloyi 2001:11-20).

Moreover, there is no medical evidence to support the notion that sexual relations after menopause are a danger to health - this is nothing more than a myth perpetrated by certain African traditions. Although sexual relations after menopause may be regarded as taboo in some cultures and traditions that do not constitute the focus of this article, the fact that this view is cited as a reason for polygamy in some African cultures needs to be exposed. 
In my view it is very difficult to defend polygamy in modern times, especially given current economic circumstances. I fully support Kahiga (2007:121), who expresses the view that although it cannot be ignored, the practice of polygamy no longer has a place. Kathide (2007:41) shares this sentiment, making the observation that aside from the problems of rearing and disciplining children and quarrels amongst the wives, the harsh economic reality of modern times is sufficient to discourage polygamy, since providing a house for one wife as well as giving one child a decent education is already a great responsibility. The modern African woman is assertive of her marital rights and her right to equality and dignity, and is no longer prepared to live out her life in perpetual sexual slavery in a patriarchal system in which polygamy is used as an oppressive practice. Current socialisation as well as a culture of respect for human rights and the acknowledgement of gender equality should combine to topple polygamy as custom and tradition. Of course, oppression is encountered in some monogamous marriages, but that is another subject altogether. Mbeya (1994:16) recognises a definite connection, throughout the world, between polygamy and oppression under patriarchy and other serious forms of inequality. Although he does not explain how, Jenkins (2010:45) claims that pressure is being placed on even some of the long-established AICs to change their stance on polygamy. As Chapman (1986:28) points out:

Sharing is not for every woman, but every woman needs to open her eyes so that she can recognize when she is sharing her man with someone else. Too many women pretend that they can share in order to have a relationship and then end up overwrought with anxiety

\section{Fear of being a social outcast}

Although some African cultures are changing their stance under Western influence, others continue to treat unmarried women as outcasts. It is the duty of the church, through its leadership, to teach that marriage is indeed part of life, but that life can still be enjoyed by those who choose to remain single. There is no reason to force a woman into a polygamous marriage to prevent her becoming a social outcast: just as marriage is all about commitment, singleness is also a legitimate choice (Baloyi 2010:11). Denis and Ntsimane (2006) report on the current phenomenon of women who choose not to be married, but nevertheless have children, but for the purpose of this article I wished to draw attention specifically to the negative connotations of being unmarried and how this is exploited as a reason for polygamy. The traditional fear of being single is one that needs to be addressed through counselling, so that people are able to accept themselves as they are. As Fagerstom (1996:77) suggests, we should not look to others for approval and self-esteem, but to the One who created us. 


\section{Health and economic considerations}

If health-related problems are encountered if the husband and wife engage in sexual relations during pregnancy and nursing, the best advice one can give them is to consult their family doctor. In contemporary society, any man who marries a second wife because of such problems needs to remember that, in doing so, he may well be exposing himself and the whole family to the HI virus -aside from the fact that marrying a second wife for such reasons is obviously unfair to his first wife. If the problem is not health-related, then the church has a moral obligation to teach the couple to stay together.

It must be remembered that in earlier times in Africa, polygamy was a way of life that could be practised only by wealthy men who could afford to take care of a number of wives and a great many children (Wunderink 2009:17). Our communities should therefore be educated and actively encouraged to have families that they can afford to support. South Africa is currently facing a very high level of unemployment, It would be extremely unwise for an economically deprived or unemployed man to practice polygamy. It is not only unethical, but also extremely irresponsible to have a larger family than one can afford to support. In those cultures where a surviving brother is obliged to inherit his deceased brother's wife, the family, clan, community and local pastors have a moral obligation to review this custom in light of the wishes of the widow, and health-related considerations.

\section{Conclusion}

Polygamy has long been the preferred form of marriage in Africa. Nevertheless, the Christian church needs to take a decisive stand with regard to polygamists who want to join the church. Faith is the responsibility of an individual, but church is the responsibility of people, and faith manifests itself in the church. It is my conviction that understanding the constitution of different churches and their structures can enable a polygamist to choose a church which he understands and in which he can be happy; it is not necessary to point fingers at another church that has a different policy. Finally, I wish to reiterate that people should be advised to consult their doctors concerning infertility, menopause, child-rearing and other related issues before they invoke polygamy as a solution to any of these problems, and that men should be advised to take the cost of living into account before deciding to marry a second wife. I would like to conclude with the words of Olukoya (2004:258): "The spirit of multiplication of wives and concubines causes disaffection and frustration in monogamy, and has destroyed many promising destinies. It is the root of most divorces, remarrying and early widowhood.” 


\section{References}

Baloyi, ME. 2001. Counselling Christian Shangaans on choosing a marriage partner. MA dissertation: Potchefstroom.

Baloyi, ME. 2010. Pastoral care and the agony of female singleness in the African Christian context. In Die Skriflig, 44(3).

Blum, WGB. 1989. Forms of marriage. Monogamy reconsidered. Nairobi: AMECEA Gaba Publications.

Burman, S. 1991. Illegitimacy and the African family in a changing South Africa. Acta Juridica: 36-51.

Cairncross, J. 1974. After polygamy was made a sin. The social history of Christian polygamy. London: Routledge and Kegan Paul.

Chapman, AB. 1986. Man sharing: dilemma or choice, a radical new way of relating to the men in your life. New York: William Morrow and Company.

De Bruyn, N. 1988. Accept polygamy as an African tradition, WCC told. Special Reports from the Eighth Assembly of the World Council of Churches, 3-14 December 1988, Harare, Zimbabwe. (www.eni.ch/assembly/0580.html). Last visited on 2012-07-20.

Denis, P \& Ntsimane, R. 2006. Absent fathers: why do men not feature in stories of families affected by HIV/AIDS in KwaZulu-Natal? In Linda Richter and Robert Morrell (eds), Baba: men and fatherhood in South Africa. Cape Town: HSRC Press.

Vos, P. 2010. Is polygamy unconstitutional? Constitutionally speaking (http://constitutionallyspeaking.co.za).

Fagerstom, DG. 1996. Counselling single adults: a handbook of principles and advice. Grand Rapids, MI: Baker.

Fenske, J. 2011. African polygamy: past and present. In Modern and comparative economy seminar, 3 November 2011, London School of Economic and Political Science. Unpublished paper delivered at the University of Oxford.

Ford, M. 2007. African women theologians: a contextual study of the Circle of Concerned African Women Theologians. Leiden: Brill.

Gaskiyane, I. 2000. Polygamy: a cultural and biblical perspective. London: Piquant.

Gold, J. 2007 Polygamy as a pre-requisite for church membership? Biblical misunderstandings in Africa. Posted on 03 April 2007, 9:58. (www.christiantoday.com/article/polygamy.a.prequisite).

Hillman, CSSP. 1975. Polygamy reconsidered. African plural marriage and the Christian African Churches. Maryknoll: Orbis Books.

Jenkins, P. 2010. One man, one woman? The paradox of polygamy. Notes from the Global Church. Christian Century. (http://www.christiancentury.org/article/2010-01/one-man-one-woman) 
Kahiga, JK. 2007. Polygamy: A pastoral challenge to the church in Africa. Specific challenges to evangelization in Africa. African Ecclesial Review, 49(1 \&2), March-June 2007: 119-147.

Karimi, F. 2012 South African president marries fourth wife. CNN. 21 April 2012. (http://articles.cnn.com).

Kimathi, G. 1994. Your marriage and family. Wetenskaplike bydraes. Potchefstroom University for Christian Higher Education. Series F2 no. 58.

Kofon, NE. 1992. Polygyny in pre-Christian Bafut and new moral theological perspectives. Frankfurt: Peter Lang.

Kriel, JD. 1991. Traditional marriages amongst blacks. Lantern 40, Aug: 27-29.

Kyomo, AA \& Selvan, SG. 2004. Marriage and family in African Christianity. Nairobi: Acton.

Labeodan, H.A., 2007, The Yoruba belief system and its impact on women's reproductive health, Journal of Constructive Theology 13(1), 39-55.

Landman, C. 2010 Christene en poligamie. Lit Net, 18 June.

Maillu, DG. 1988. Our kind of polygamy. Nairobi: Heinemann.

Majeed, DM. 2004. The battle has been joined. Gay and polygynous marriages are out of the closet and in search of legitimacy. Crosscurrent, Summer: 73-81.

Maldonado, M., n.d., Cultural issues during pregnancy, viewed 26 October 2011, from http://www.authorstream.com/Presentation/Stentore-41340-cultural-issues-durin g-pregnancy-Culture-general-as-Education-ppt-powerpoint.

Masenya, M. 2005. The Bible, HIV/AIDS and African-South African women: a bosadi (womanhood) perspective. Studia Historiae Ecclesiasticae, XXXI(1), June: 187-201.

Mbeya, CM. 1994. A voice from Zaire. Daughters of Sara, Spring.

Mbiti, JS. 1969. African religions and philosophy. New York: Praeger.

Modupe, AN. [S.a.] Law and social values: polygamy or extra-marital affairs (www.unilorin.edu.ng).

Mugambi, JNK. 1989. African heritage and contemporary Christianity. Nairobi: Longman.

Nhlapo, TR. 1991. The African family and women's rights: friends or foes? Acta Juridica: 135-146.

Nkhwashu, G. 2012. Culture shock for rich widow. Daily Sun. 25 July: 1-2.

Njoroge, N. 1997. The missing voice. African women doing theology. Journal of Theology for Southern Africa, 99, November: 77-83.

Okonkwo, E. 2003. Marriage in the Christian and Igbo traditional context: towards an inculturation. Berlin: Peter Lang.

Okorie, AM. 1995. African widowhood practices: the Igbo mourning experience. Africa Journal of Evangelical Theology, 14(2): 79-84. (www.theoledafrica.org) Last visited on 01-08-2012. 
Olukoya, DK. 2004. Prayer warfare against 70 mad spirits. Lagos: Battle Cry Christian Ministries.

Peil, M \& Oyeneve, O. 1998. Consensus, conflict and change. Nairobi: East African Educational Publishers.

Phaswana, DR. 2005. Counselling singles. Unpublished paper delivered at the meeting of the Reformed minister's think tank: Iyani Bible School (Venda).

Phiri, IA. 2002. Why does God allow our husbands to hurt us? Overcoming violence against women. Journal of Theology for Southern Africa, 114: 10-30.

Phiri, IA. 2006. The Bible and polygamy. In Tokunboh Adeyemo (ed), Africa Bible commentary. London: Piquant.

Phiri, IA. 2007, Women, Presbyterianism and patriarchy. Religious experience of Chewa women in central Malawi. Zomba, Malawi: Khachere Series.

Reynolds, J. 2008. The single woman. London: Routledge.

Shahzad, S. 2009. Polygamy - a socio-religious conundrum. (https://groups.google.com/ forumgroups). Last visited on 2012-07-20.

Struensee, SV. 2004. The contribution of polygamy to women's oppression and Impoverishment: an argument for its prohibition. Social science research network (http://papers.ssrn.com).

Townshend, PO. 2008. A gender-critical approach to the Pauline material and the Zimbabwean context with specific reference to the position and role of women in selected denominations. Unpublished Master of Theology dissertation, University of South Africa.

Turaki, Y. 1999. Christianity and African gods: a method in theology. Wetenskaplike bydraes. Potchefstroom University for Christian Higher Education. Series F2 no. 75.

Waruta, DW \& Kinoti, HW. 2000. Pastoral care in African Christianity. Nairobi: Acton.

Wunderink, S. 2009. What to do about polygamy? African churches seek a better response than in the years past. Christianity Today, July: 17-18.

Yamani, MAZ. 2008. Polygamy and law in contemporary Saudi Arabia. London: Ithaca. 